\title{
TINJAUAN BUKU
}

\section{Panduan bagi Ahli Bahasa dan Pemelajar Bahasa-bahasa Austronesia}

Alexander Adelaar dan Nikolaus P. Himmelmann, ed. 2005. The Austronesian Languages of Asia and Madagascar, (London: Routledge,2005), xxi + 841 halaman.

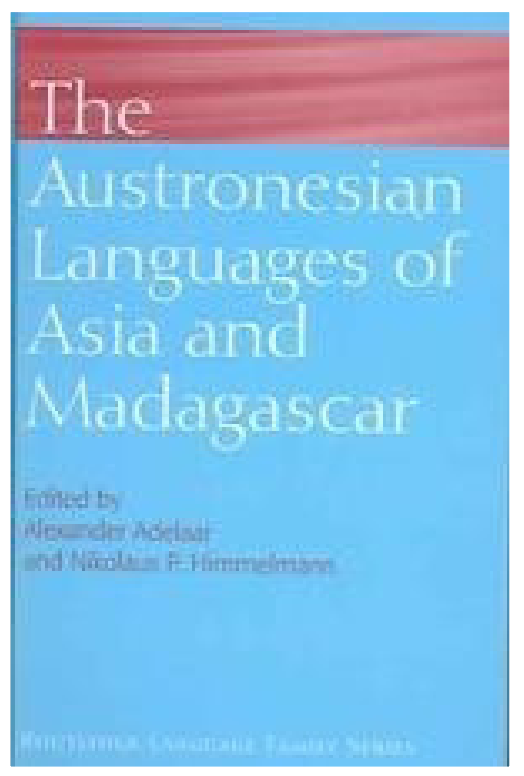

Sekarang ada kira-kira 6.000 bahasa di dunia dan ada pendapat bahwa hampir 90 persennya akan punah sampai akhir abad ke-21. Hal itu terjadi karena dominasi pemakaian beberapa bahasa yang menjadi bahasa antarabangsa akibat globalisasi. Dengan demikian, pengarsipan dan penelitian bahasa-bahasa daerah yang masih hidup merupakan satu tugas yang penting bagi para ahli linguistik.

Wilayah kelompok bahasa Austronesia, yaitu dari kepulauan Madagaskar hingga Rapanui (Kepulauan Timor), adalah tempat yang mempunyai ciri-ciri menarik dalam bahasanya. Wilayah itu menjadi salah satu tempat yang harus dicatat secepat mungkin karena kini perluasan bahasabahasa nasional di mana pun masingmasingnya mengurangi jumlah penutur asli yang belum dicacat secara deskriptif. Pencatatan bahasa daerah di wilayah Austronesia penting karena akan menghasilkan bermacam-macam pandangan yang baru dalam bidang linguistik di samping mengembangkan ilmu itu sendiri.

Buku The Austronian Languages of Asia and Madagascar ini merupakan satu panduan yang cemerlang bagi peminat-peminat kelompok bahasa Austronesia itu.

Buku ini disusun oleh Alexander Adelaar dan Nikolaus P. Himmelmann dan memuat 28 tesis yang ditulis oleh para ahli bahasa Austronesia. Secara keseluruhan, penelitian dalam bidang linguistik dan antropologi dalam buku ini meliputi tema-tema "The Austronesian Languages of Asia and Madagascar: 
A Historical Perspecitive", "Language shift and Endengerment, Colonial History and Language Policy in Insular Southeast Asia and Madagascar", "Ritual Languages, Special Registers and Speech Decorum in Austronesian Languages", "The Austronesian Languages of Asia and Madagascar: Typological Chacteristics", dan "Structual Diversity in the Malayic Subgroup". Sketsa-sketsa tata bahasa (grammar sketch) dalam buku ini meliputi bahasa Melayu Kuno, bahasa Indonesia Kolokial, Tsou, Seediq, Iloko, Tagalog, Sama (Bajau), Kimaragang, Belait, Malagasy, Phan Rang Cham, Moken dan Moklen, Karo Batak, Nias, Jawa, Buol, Makassar, Mori Bawah, Kambera, Tetun dan Leti Taba, Biak.

Sebagai tulisan payung di dalam buku tersebut, "The Austronesian Languages of Asia and Madagascar: A Historical Perspective", yang ditulis oleh karya Alexander Adelaar, dan "The Austronesian Languages of Asia and Madagascar: Typological Characteristics" karya Nikolaus P. Himmelmann sebaiknya dibaca terlebih dahulu. Tulisan itu akan memberikan pemahaman baik bagi pembaca yang sudah secara mendalam mempelajari bahasa maupun bagi pembaca yang belum menangkap ciri-ciri seluruh dan sebagian wilayah kelompok bahasa Austronesia. Tulisan "The Austronesian Languages of Asia and Madagascar: A Historical Perspective", karya Alexander Adelaar, salah seorang Austronesianis yang mempelajari perubahan historis, terutama dalam bidang fonetis, menerangkan klasifikasi bahasa-bahasa Austronesia, tanah air (homeland), serta pemindahan orang-orang Austronesia dan kontak bahasanya secara diakronis. Tulisan “The Austronesian languages of Asia and Madagascar: Typological Chacteristics", karya Nikolaus P. Himmelmann, salah seorang Austronesianis yang mempelajari bahasa-bahasa Filipina, menunjukkan ciriciri sinkronis berbagai hal dalam kelompok bahasa Austronesia, mulai dari ciri-ciri fonetis hingga sintaktis, secara jelas dan lengkap. Tiap nama bahasa contohan yang mempunyai ciri khusus ditunjukkan setelah penjelasannya, demikian pula dengan deskripsi bahasanya. Dengan demikian, pembaca pasti dapat menikmati merujuk bahan-bahan bahasanya.

Semua sketsa tata bahasanya ditulis dalam kira-kira dua puluh halaman secara lengkap dan mudah dipahami. Peristilahan dalam sketsa tata bahasa tiap bahasa yang dideskripsikan konsisten sehingga mudah dipahami. Sebagai contoh, deskripsi diatesis (voice) mempunyai istilah bermacam-macam tergantung kepada bahasanya, tetapi dalam buku ini, istilah actor voice, undergoer voice, dan lain-lain sajalah yang dipergunakan secara konsisten dari satu tulisan ke tulisan yang lain. Himmelmann, dalam artikel "The Austronesian Languages of Asia and Madagascar: Typological Chacteristics", menguraikan bahwa bermacam-macam istilah dapat dipakai untuk penjelasan-penjelasan sistem diatesis, terutama dalam bahasa-bahasa yang mempunyai banyak diatesis, namun contoh-contoh yang disajikan dalam tulisan itu adalah contoh-contoh yang menonjol dan mudah dipahami saja. Penyuntingan dan penjelasan ini boleh dikatakan membantu para pembaca tidak mencampurkan istilah dan maknanya. 
Salah satu muatan yang paling menarik bagi saya adalah deskripsi tentang sistem diatesis dalam artikel Himmelmann tentang masalah kebahasaan Austronesia secara tipologis. Menurut Himmelmann, ada dua jenis alternasi diatesis dalam bahasa-bahasa Austronesia barat, yaitu alternasi pasif dan alternasi diatesis simetri (symmetrical voice alternations, yang juga dikenal sebagai "Philippine-type focus" alternations, meskipun Himmelmann menyatakan bahwa istilah "fokus" tidak cocok dalam konteks ini). Kebanyakan bahasa Austronesia memuat alternasi diatesis yang mirip pertautan aktifpasif yang terkenal dalam bahasa-bahasa Eropa. Kalimat pasif seperti itu mempunyai kriteria berikut: (a) verbanya ditandai dengan pembentuk pasif; (b) pengalam (undergoer; sejenis peranan semantis) verba transitif merupakan subjek dalam konstruksi; dan (c) pelaku (actor) mungkin tidak ditunjukkan, atau, walaupun ditunjukkan, ditandai sebagai oblik (oblique), yang biasanya dengan kata depan. Tambahan lagi, Himmelman menjelaskannya dengan kalimat-kalimat contohan berikut.

(1) Orang itu di-lihat anak saya.

(2) Orang itu di-lihat oleh anak saya.

Kalimat (1) dan (2) hampir sama strukturnya, kecuali penambahan kata depan oleh dalam kalimat (2). Himmelmann menyimpulkan bahwa bahasa Indonesia baku memuat pasif "standar" (seperti dalam (2)) dan alternasialternasi diatesis simetri (seperti dalam (1)). Menurutnya, fenomena ini mungin ada juga dalam bahasa-bahasa yang mempunyai alternasi-alternasi diatesis simetri, seperti bahasa-bahasa bertipe bahasa Filipina (Philippinetype). Di samping itu, dia menjelaskan bahwa sistem diatesis dalam bahasabahasa Filipina, Formosa (Taiwan asli), serta sebagian Sabah dan Sulawesi biasanya memuat empat alternasi, yaitu diatesis pelaku (actor voice), diatesis pasien (patient voice), diatesis lokatif (locative voice), dan diatesis pembawaan (convayance voice) dalam bahasa Cebuano sebagai contoh. Menurutnya, kalaupun terdapat diatesis beralternasi empat ke atas, dalam kebanyakan kasus, alternasi itu hanyalah tambahan yang memuat ekoran berupa gabungan afiks pembetuk pangkal dan afiks diatesis dasar (misalnya, prefiks "diatesis instrumental (instrumental voice)" ipaN- dalam bahasa Tagalog terdiri atas prefiks pembentuk pangkal $p a N$ - dan prefiks diakronis bawaan $i$-). Penjelasan tentang diatesis yang ditulis oleh Himmelmann ini memang akan menjadi aliran besar dalam bahasa-bahasa Austronesia.

Sayangnya buku ini tidak memuat penjelasan sintaksis, khususnya susunan kata dan sebagainya, selengkap penjelasan dalam bidang yang lain, kecuali dalam beberapa bahasa yang mementingkan sintaksis daripada morfologis, atau yang aspek morfologisnya tidak begitu rumit, seperti sketsa bahasa Indonesia ragam percakapan atau colloquial Indonesian. Oleh karena halamannya dibatasi, kecenderungan isi pun dapat terlihat: Ada yang mementingkan fonetik historis, contohnya sketsa bahasa Melayu kuno; ada yang mementingkan morfologis verba (contohnya sketsa bahasa Taba). Hal itu disebabkan ciri-ciri yang menonjol pada bahasa yang dideskripsikan. Selain itu, agaknya kecenderungan yang seperti itu juga dipengaruhi oleh minat 
penulis masing-masing.

Setakat ini, agaknya tidak terdapat penerbitan bahan akademis tentang seluruh bahasa Austronesia sebesar yang dikumpulkan dalam buku tersebut. Tambahan pula, mungkin penerbitan buku seperti itu terlalu sulit sekarang ini, dan mungkin seterusnya. Oleh karena itu, buku tersebut akan menolong mengurangi upaya yang menjemukan untuk mencari bahan-bahan sebidang dalam jurnal dan buku.

Sedalam-dalam penulis dalam buku ini sudah menerangkan fakta bahasa dalam rumpun bahasa Austronesia dan bahasa-bahasa yang berkembang masing-masing, agaknya muncul deskripsi dan/atau istilah yang tidak cocok bagi aliran atau pengetahuan tiap pembaca. Namun, bagi peminat linguistik deskriptif yang belum memulai penelitian, penjelasan dalam buku ini menjadi bantuan yang gemilang, karena tesis, termasuk acuannya, akan memberi pengetahuan yang meluaskan penelitian.

Buku ini layak dan penting dibaca baik oleh ahli bahasa maupun pemelajar yang ingin mempelajari linguistik bahasa-bahasa Austronesia, selain juga menjadi rujukan yang baik. Barangkali buku ini akan menjadi pilihan pertama yang memandu pembaca untuk melayari kelautan linguistik Austronesia dengan selamat: selagi memegang buku ini, tidak berlebihan, saya yakin pembaca tidak akan tersesat.

Yuko Kitada
Program Studi Linguistik, Tokyo University of Foreign Studies, Tokyo, Jepang

\section{Membuka Kedok Korupsi dalam Masyarakat}

Al. Andang L.Binawan (ed). Korupsi Kemanusiaan. Jakarta: Penerbit Buku Kompas, 2006), xx + 234 halaman.

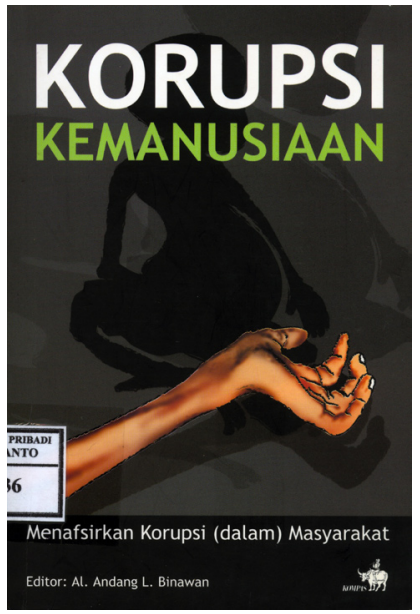

Buku ini merupakan kumpulan karangan festschrift (penghormatan) terhadap Romo Magnis Suseno pada hari ulang tahunnya ke- 70. Kumpulan karangan yang menguraikan tafsir korupsi dari sudut pandang etika, nilai humanistis dan sosial budaya. Berbagai perspektif diuraikan dengan gamblang dan mudah dipahami, seperti: praktik korupsi yang sanggup merusak wacana tentang korupsi, logika koruptif dalam kerja jurnalistik, cengkeraman kapitalisme transnasional, pembusukan pandangan terhadap dunia, kekuasaan voyeuristik dalam masyarakat, hakikat manusia Feuerbachian, eksistensi manusia, penghayatan hidup individu, toleransi moral 